ISSN 0081-7147

e-ISSN 2451-1331

\title{
Kodeks Baltazara Behema jako świadectwo miejskiej ideologii władzy
}

Zarys treści: Niniejsze rozważania dotyczą politycznych i ideowych uwarunkowań sporządzenia kodeksu Baltazara Behema, bogato iluminowanego kopiariusza rady miejskiej Krakowa z pierwszych lat XVI stulecia. Zgodnie z główną tezą artykułu, kodeks Behema powstał w latach 1503-1505 jako fundacja krakowskiej rady miejskiej i wyrażał oficjalną miejską ideologię władzy. Program ideowy kodeksu stanowił również odpowiedź na wyzwania polityczne wywołane reformą ustroju państwowego za panowania Aleksandra Jagiellończyka.

\begin{abstract}
The present reflections are devoted to the political and ideological circumstances of the compilation of the so-called Codex of Baltazar Behem, a richly-illuminated cartulary of the municipal council of the city of Cracow from the early years of the $16^{\text {th }}$ century. According to the main argument of the article, the codex was made in 1503-1505 as the foundation of the Cracow city council and expressed the official urban ideology of power. The ideological programme of the codex was at the same time a response to political challenges resulting from the reform of state political system under King Alexander Jagiellon.
\end{abstract}

Słowa kluczowe: kopiariusz, iluminowany rękopis, heraldyka miejska, pieczęć miejska, ideologia komunalna, rytuał władzy

Keywords: cartulary, illuminated manuscript, urban heraldry, urban seal, communal ideology, ritual of power

Kodeks Baltazara Behema to uroczysty kopiariusz rady miasta Krakowa sporządzony na początku XVI w. ${ }^{1}$ Wziął on swoją obecną nazwę od imienia i nazwiska przełożonego krakowskiej kancelarii miejskiej w latach 1500-1508². Księga stanowiła własność samorządu Krakowa do 1825 r., kiedy Senat Rządzący Wolnego Miasta Krakowa przekazał ją do Biblioteki Jagiellońskiej. Po zaginięciu w trakcie II wojny światowej kodeks wrócił do BJ i jest tam przechowywany do dziś pod XIX-wieczną sygnaturą nr $16^{3}$. Pierwotnie kopiariusz składał się z 372 pergaminowych kart o wymiarach 32,7 x 24,3 cm. Jego pierwszy redaktor wpisywał do niego kopie dokumentów, zwłaszcza przywilejów, a także roty przysiąg składanych przez urzędników miejskich, kupców i rzemieślników oraz teksty wilkierzy i statutów cechowych. Kodeks Behema otrzymał bogatą i oryginalną dekorację miniatorską, wyróżniającą go na

${ }^{1}$ BJ, rkps 16; wyd. faksymilowe: Codex Picturatus Balthasaris Behem. Facsimile, Varsoviae-Cracoviae [1989].

2 Badania nad życiem Baltazara Behema podsumował M. Starzyński, Kto byt pisarzem „,Kodeksu Behema”?, „Rocznik Krakowski", 73, 2007, s. 64; por. K. Estreicher, Behem Baltazar, w: PSB, t. 1, Kraków 1935, s. 398 n.

${ }^{3}$ Katalog rękopisów Biblioteki Uniwersytetu Jagiellońskiego, cz. 1, oprac. W. Wisłocki, Kraków 1877-1881, s. 6; Katalog łacińskich rękopisów średniowiecznych Biblioteki Jagiellońskiej, t. 1, oprac. Z. Włodek, J. Zathey, M. Zwiercan, Wrocław 1980, s. 6-18. 
tle wielu podobnych iluminowanych ksiąg, które powstawały w kancelariach miast średniowiecznej i nowożytnej Europy ${ }^{4}$. Iluminowane kodeksy, gromadzące zwykle teksty o tematyce prawnej (tzw. codices picturati), należały obok tłoków pieczętnych do najcenniejszego wyposażenia dawnych kancelarii miejskich. Na obszarach oddziaływania niemieckich wzorców kultury miejskiej zwyczaj posługiwania się takimi księgami sięgał jeszcze XIII w., kiedy powstawały pierwsze iluminowane rękopisy Zwierciadła saskiego ${ }^{5}$. Najbliższą terytorialnie analogię dla krakowskiego kodeksu Baltazara Behema stanowi iluminowana księga prawa Głubczyc, sporządzona w $1421 \mathrm{r}^{6}$

Naukowe badania nad kodeksem Baltazara Behema zainaugurowało studium historyczno-archiwalne autorstwa cenionego prawnika i historyka Udalryka Heyzmanna, opublikowane w 1865 r. $^{7}$ W późniejszym czasie zagadnienie genezy i autorstwa kodeksu Behema rozpatrzył szczegółowo Jan Ptaśnik $^{8}$. Równocześnie krakowski kopiariusz stał się jednak przede wszystkim przedmiotem wytężonych studiów historyczno-artystycznych ${ }^{9}$. Bodźców do wznowienia rozważań nad powstaniem i funkcjami kodeksu Behema dostarczyły wyniki badań kodykologicznych Anny Sobańskiej ${ }^{10}$. Aktualny etap dyskusji nad wspomnianymi zagadnieniami wyznaczają rozprawy Marcina Starzyńskiego i Patrycji Wiencierz ${ }^{11}$. Badacze ci wzmocnili opinię, zgodnie z którą Baltazar Behem nie był pisarzem kodeksu, a jedynie nadzorował prace nad księgą ${ }^{12}$. Pozostają oni również zgodni w kwestii datowania prac nad księgą. Wstępną, uroczystą część kodeksu spisano ich zdaniem w latach 1503-1505, przy czym sam kopiariusz mógł zacząć powstawać wcześniej, w niekreślonym momencie po objęciu przez Behema stanowiska pisarza miejskiego w 1500 r. Mimo ofiarowania kodeksu rajcom w 1505 r., pozostał on nieukończony i pracowano przy nim jeszcze jakiś czas, być może aż do nagłej śmierci Behema podczas zarazy w $1508 \mathrm{r}$.

${ }^{4}$ Zob. Miniatury z Kodeksu Baltazara Behema, fot. J. Podlecki, koment. M. Fabiański, Kraków 2000.

${ }^{5}$ R. Schmidt-Wiegand, Text und Bild in den Codices picturati des „,Sachsenspiegels”. Überlegungen zur Funktion der Illustration, w: Text-Bild Interpretation. Untersuchungen zu den Bilderhandschriften des Sachsenspiegels, red. D. Hüpper, München 1986, s. 11-31; taż, Die Bilderhandschriften des Sachsenspiegels als Zeugen pragmatischer Schriftlichkeit, „Frühmittelalterliche Studien”, 22, 1988, nr 1, s. 357-387; taż, Rechtsbücher in städtischem Besitz und das Beispiel Leobschütz, w: Stadtgeschichte Oberschlesiens. Studien zur städtischen Entwicklung und Kultur einer ostmitteleuropäischen Region vom Mittelalter bis zum Vorabend der Industrialisierung, red. Th. Wünsch, Berlin 1995, s. 136 n.; zob. też H.S. Hayduk, Rechtsidee und Bild. Zur Funktion und Ikonografie der Bilder in Rechtsbücher vom 9. bis zum 16. Jahrhundert, Wiesbaden 2011, s. 99 n.

${ }^{6}$ Das „Leobschützer Rechtsbuch”, oprac. G. Roth, red. W. Irgang, Marburg 2006; zob. też R. Schmidt-Wiegand, Rechtsbücher in städtischem Besitz, s. $158 \mathrm{n}$.

${ }^{7}$ U. Heyzmann, Balthazaris Behem Codex Picturatus anno 1505, continens privilegia et plebiscita urbis Cracoviae, „Archiv für Kunde österreichischer Geschichts-Quellen", 33, 1865, s. 163-231.

8 J. Ptaśnik, Codex picturatus Baltazara Behema. Problem autorstwa, Kwart. Hist., 44, 1930, nr 1, s. 1-25.

${ }^{9}$ Kluczową rolę w rozwoju profesjonalnych badań historyczno-artystycznych nad kodeksem Baltazara Behema odegrało zwłaszcza studium K. Estreichera, Miniatury Kodeksu Bema oraz ich treść obyczajowa, „Rocznik Krakowski”, 24, 1933, s. 199-244; zob. też W. Terlecki, Ze studiów nad miniatura polska XVI wieku, „Sprawozdania Towarzystwa Naukowego we Lwowie”, 10, 1930, nr 1, s. 15-20. Należy też odnotować monografię F. Winklera, Der Krakauer Behaim-Codex, Berlin 1941. Rezultaty dalszych badań podsumowują: Z. Ameisenowa, Kodeks Baltazara Behema, Warszawa 1961; taż, Rękopisy i pierwodruki iluminowane Biblioteki Jagiellońskiej, Wrocław-Kraków 1958, s. 160-174; B. Miodońska, Małopolskie malarstwo książkowe 1320-1540, Warszawa 1993, s. 175 n.; taż, Kodeks Baltazara Behema, w: Malarstwo gotyckie w Polsce. Katalog zabytków, red. A.S. Labuda, K. Secomska, Warszawa 2004, s. 370-372; Z. Rozanow, Mieszczańskie uniwersum Kodeksu Baltazara Behema, w: Sztuka miast i mieszczaństwa XV-XVIII wieku w Europie Środkowowschodniej, red. J. Harasimowicz, Warszawa 1990, s. 205-216; taż, Sekrety miniatur Kodeksu Baltazara Behema, Katowice 2017.

10 A. Sobańska, Kodeks Baltazara Behema. Komentarz kodykologiczny, Kraków 2007.

${ }^{11}$ M. Starzyński, Kto byt pisarzem, s. 61-71; P. Wiencierz, Kodeks Baltazara Behema jako kopiariusz. Nowe dyskusje i nowe ustalenia, „Rocznik Krakowski”, 84, 2018, s. 7-32.

12 Opinię tę wyraziła jako pierwsza Z. Rozanow, Mieszczańskie uniwersum, s. 206. Przekonanie to starała się podważyć ostatnio A. Sobańska, Kodeks Baltazara Behema, s. 13. Z opinią A. Sobańskiej polemizował zwłaszcza M. Starzyński, Kto byt pisarzem, s. 67 n. We wcześniej opublikowanym artykule M. Starzyński twierdził jednak, że inicjatorem prac nad kodeksem i jego fundatorem był Baltazar Behem; tenże, Dwa nekrologi Jana Olbrachta (z krakowskiej księgi radzieckiej i Kodeksu Baltazara Behema), Rocz. Hist., 72, 2006, s. 129, 131. 
M. Starzyński i P. Wiencierz odmiennie interpretują natomiast przyczyny sporządzenia kodeksu i jego funkcje. Pierwszy z badaczy uważa, że kopiariusz powstawał pod nadzorem Baltazara Behema jako oficjalna fundacja rady miejskiej w celu usprawnienia działalności kancelarii miejskiej ${ }^{13}$. Z kolei P. Wiencierz twierdzi, że fundatorem księgi, a może nawet pomysłodawcą jej wykonania, był sam Behem, a powstały $\mathrm{z}$ jego inicjatywy kopiariusz mógł pełnić funkcje insygnium władz miejskich ${ }^{14}$. Autorka poruszyła to ostatnie zagadnienie również we wcześniej opublikowanym artykule ${ }^{15}$. Odwołała się w nim mianowicie do obecnej w starszej literaturze hipotezy, zgodnie z którą jedna z miniatur kodeksu Behema, ukazująca Ukrzyżowanie, mogła być wykorzystywana podczas rytuału przysięgi miejskiej ${ }^{16}$. P. Wiencierz uważa co prawda, że przedstawienie Ukrzyżowania zostało umieszczone w kodeksie Baltazara Behema wyłącznie w celu podniesienia prestiżu tej księgi ${ }^{17}$, równocześnie jednak nie wyklucza ona możliwości, że kodeks Behema był wykorzystywany w miejskim rytuale władzy podczas uroczystości zaprzysiężenia rajców.

Oceniając rezultaty rozważań M. Starzyńskiego i P. Wiencierz, należy podkreślić, że nie tylko przyczyniły się one do uporządkowania wyników dotychczasowych badań nad kodeksem Baltazara Behema, lecz także znacząco pogłębiły naszą wiedzę o budowie, zawartości i datowaniu krakowskiego kopiariusza. Rozprawy te nie przyniosły natomiast rozstrzygających konkluzji dotyczących powodów powstania kodeksu ani jego funkcji symbolicznych ${ }^{18}$. Wskazane zagadnienia będą przedmiotem niniejszych rozważań.

Zacznijmy od ustosunkowania się do ustaleń dotyczących momentu rozpoczęcia prac pisarskich przy kodeksie Baltazara Behema. Kluczowe znaczenie dla dyskusji nad tym problemem ma analiza struktury pierwszych składek kopiariusza. Kodeks rozpoczynał się pierwotnie od siedmiu wstępnych, nienumerowanych kart. W drugiej połowie XIX w., przy okazji sporządzania nowej oprawy, zostały one poprzedzone jeszcze jedną kartą i spaginowane, przez co pierwsza oryginalna karta kodeksu jest obecnie oznaczana jako druga ${ }^{19}$. Na jej pierwszej stronie zapisano skład rady miejskiej Krakowa urzędującej w 1503 r., a u góry dopisano formułę informującą o ukończeniu całości kodeksu w 1505 r.: „Anno Domini 1505 consummatum". Na odwrocie karty wpisano skład rady starszej z 1503 r. ${ }^{20}$, a na k. $3 \mathrm{r}-4 \mathrm{r}$ wpisano list dedykacyjny Baltazara Behema, opatrzony jego gmerkiem oraz datą dzienną 23 XII $1505^{21}$. $\mathrm{Na}$ k. 4v znajduje się miniatura przedstawiająca herb miasta Krakowa, a na k. 5r-7r wpisano przywilej lokacyjny z 1257 r. Odwrocie k. 7 pozostawiono puste, a na k. 8r-v przepisano przywilej Leszka Czarnego z 1288 r. $^{22}$ Od k. 8r rozpoczyna się oryginalna numeracja (foliacja) kart kopiariusza, nadana w kancelarii miejskiej. Pierwsza oryginalna karta kodeksu, zawierająca skład rady miejskiej z 1503 r., stanowi całość (jako bifolium) z ósmą kartą księgi, zawierającą tekst przywileju Leszka Czarnego

${ }^{13}$ M. Starzyński, Kto byt pisarzem, s. 62 n.; tenże, rec.: A. Sobańska, Kodeks Baltazara Behema. Komentarz kodykologiczny, Kraków 2007, St. Źródł., 47, 2009, s. 256.

${ }_{14}$ P. Wiencierz, Kodeks Baltazara Behema, s. 26-28.

15 Taż, Iuramentum na inaugurację władzy w mieście średniowiecznym. Przykład Krakowa, Czas. Pr. Hist., 69, 2017, nr 2, s. $349 \mathrm{n}$.

${ }^{16}$ L. Lepszy, Studia nad ornamentyka kodeksów miniaturowych polskich, „Przemysł Artystyczny”, 1, 1896, s. 6; Z. Ameisenowa, Codex Picturatus Baltazara Behema, „Sztuki Piękne”, 1, 1924-1925, s. 537; B. Miodońska, Kodeks Baltazara Behema, s. 371.

${ }^{17}$ Badaczka powołuje się na opinię K. Estreichera, Miniatury Kodeksu Bema, s. 237, przyp. 1, i S. Sawickiej, Nieznany krakowski rękopis iluminowany z poczatku XVI wieku, „Studia Renesansowe”, 2, 1957, s. 74, przyp. 38.

${ }^{18}$ Potrzebę pogłębienia rozważań w tym kierunku sygnalizowałem w tekście Oficjalna przeszłość miasta, w: Przeszłość w kulturze średniowiecznej Polski, t. 2, red. H. Manikowska, Warszawa 2018, s. $181 \mathrm{n}$.

19 A. Sobańska, Kodeks Baltazara Behema, s. 10 n.

${ }^{20}$ M. Starzyński, Kto byt pisarzem, s. 63; Z. Noga, Urzędnicy miejscy Krakowa, cz. 2: 1500-1794, Kraków 2008, s. 5.

${ }^{21}$ List dedykacyjny wydał U. Heyzmann, Balthazaris Behem Codex Picturatus, s. 175-177. Treść listu analizują dogłębnie H.S. Hayduk, Rechtsidee und Bild, s. 33 n.; P. Wiencierz, Kodeks Baltazara Behema, s. 26 n. W sprawie interpretacji gmerku Baltazara Behema zob. Z. Ameisenowa, Czyim herbem jest herb Szeliga w Kodeksie Behema?, „Biuletyn Historii Sztuki”, 16, 1954, nr 3, s. 315-318; Z. Wdowiszewski, W sprawie herbu Szeliga w Kodeksie Behema, „Biuletyn Historii Sztuki”, 17, 1955, nr 1, s. 162 n.; A. Kot, Gmerk Baltazara Behema w dziele Albertusa de Eyb „,Margarita Poetica”, „Biuletyn Biblioteki Jagiellońskiej”, 52, 2002, s. 93-96; M. Starzyński, Kto byt pisarzem, s. 67-71.

${ }^{22}$ KDm.K, t. 1, nr 2. 
i rozpoczynającą właściwy kopiariusz ${ }^{23}$. Prawdopodobnie zatem twórcy kopiariusza od razu planowali poprzedzenie go uroczystą, wstępną częścią.

Datowanie wstępnej partii kodeksu zdaje się nie nasuwać poważniejszych wątpliwości. Przyjmuje się, że została ona zapisana po wyborze rajców urzędujących w 1503 r., a przed 23 XII 1505, taka data dzienna figuruje bowiem w liście dedykacyjnym, wpisanym zapewne krótko przed ofiarowaniem księgi. Prace nad właściwą częścią kodeksu, a więc nad kopiariuszem objętym oryginalną foliacją, mogłyby zostać rozpoczęte jeszcze przed zapisaniem jego części wstępnej, a zatem przed 1503 r., a po objęciu funkcji kierownika kancelarii przez Baltazara Behema w $1500 \mathrm{r}^{24} \mathrm{~W}$ takim wypadku należałoby uznać, że kodeks Behema mógł zacząć powstawać już w przedziale lat 1500-1503.

Proponowana periodyzacja nasuwa jednak poważne wątpliwości. Jeżeli prace pisarskie podjęto rzeczywiście przed 1503 r., a ofiarowanie księgi nastąpiło dopiero w 1505 r., to dlaczego na początku kodeksu postanowiono umieścić wykaz rajców z 1503 r.? Wydaje się zaskakujące, że w całej dotychczasowej historiografii zagadkę tę próbował wyjaśnić jedynie J. Ptaśnik ${ }^{25}$. Twierdził on, że Baltazar Behem planował ofiarowanie kodeksu rajcom już w $1503 \mathrm{r}$. oraz że chciał w ten sposób wzmocnić swoje szanse w staraniach o miejsce w radzie wybranej na 1503 r. Rozumowanie J. Ptaśnika nie wytrzymuje jednak krytyki. Jeżeli założymy, że Behem spodziewał się rychłego ukończenia księgi już w 1503 r., musielibyśmy uznać, że przeliczył się w swoich zamiarach o prawie dwa lata. Wydaje się to mało prawdopodobne, zważywszy, że kodeks nie był ukończony również w momencie ofiarowania go rajcom w 1505 r. Co więcej, gdyby Behem chciał umieścić na początku kopiariusza imiona i nazwiska rajców, którym ofiarował efekt swoich trudów, wstrzymałby się z tym na pewno do ostatniego momentu przed oficjalną donacją księgi. W taki właśnie sposób postąpił z listem dedykacyjnym, wpisanym do kodeksu dopiero pod koniec grudnia 1505 r. Przekonanie o dążeniu Behema do zostania rajcą w 1503 r. jest z kolei jedynie domysłem. Jeśli Behem faktycznie nosił się z takim zamiarem, nie zdołał go wypełnić również w 1505 r., gdy kodeks faktycznie ofiarowano radzie.

Wobec zgłoszonych wątpliwości sądzę, że należy przyjąć odmienną interpretację wykazu rajców z 1503 r. na pierwszej karcie kodeksu Baltazara Behema. Jeżeli nie jest to spis osób, którym Behem zamierzał ofiarować swoje dzieło, być może wykaz ten odnosi się do roku, w którym rajcy podjęli decyzję o sporządzeniu kodeksu. W takim wypadku prace nad kodeksem należałoby zamknąć w przedziale lat 1503-1505. Kopiariusz stanowiłby oficjalną fundację rady miejskiej z 1503 r., a Behem jako przełożony kancelarii miejskiej byłby tylko wykonawcą woli rajców, występując następnie w roli oficjalnego donatora księgi.

O oficjalnym charakterze fundacji kodeksu Baltazara Behema świadczy również moment ofiarowania go radzie miejskiej. Stało się to zapewne niedługo po wpisaniu do księgi listu dedykacyjnego, który nosi datę 23 XII $1505^{26} .23$ grudnia jest ostatnim świeckim dniem przed wigilią Narodzenia Pańskiego, otwierającą cykl bożonarodzeniowy w chrześcijańskim kalendarzu liturgicznym ${ }^{27}$. W czasach powstawania kodeksu Behema dzień Bożego Narodzenia traktowano wciąż jako oficjalny moment rozpoczęcia roku kalendarzowego, zgodnie z tradycyjną rachubą czasu według stylu a Nativitate $^{28}$. Okres Bożego Narodzenia zajmował również wyjątkowe miejsce w krakowskim kalendarzu ceremoniału miejskiego. Pod koniec cyklu bożonarodzeniowego, w okolicach święta Trzech Króli, w Krakowie przeprowadzono doroczną uroczystość elekcji i zaprzysiężenia członków rady miejskiej ${ }^{29}$. Kodeks Behema został więc

\footnotetext{
23 A. Sobańska, Kodeks Baltazara Behema, s. $10 \mathrm{n}$.

${ }^{24}$ M. Starzyński, Kto byt pisarzem, s. 63; P. Wiencierz, Kodeks Baltazara Behema, s. 18.

25 J. Ptaśnik, Codex picturatus, s. 5-8.

26 Ostatni przywilej wpisany do kopiariusza przed sprezentowaniem go rajcom nosi datę 16 IX 1504, a ostatni statut cechowy - 26 X 1504; BJ, rkps 16, k. 184r-186r, 278v-280v; zob. P. Wiencierz, Kodeks Baltazara Behema, s. 29.

${ }^{27}$ I. Skierska, Sabbatha sanctifices. Dzień święty w średniowiecznej Polsce, Warszawa 2008, s. 49 n., 175 n.

${ }^{28}$ G. Myśliwski, Człowiek średniowiecza wobec czasu i przestrzeni. Mazowsze od XII do pot. XVI wieku, Warszawa 1999, s. 301 n.; I. Skierska, Sabbatha sanctifices, s. 24 n.

29 Z. Noga, Krakowska rada miejska w XVI wieku. Studium o elicie władzy, Kraków 2003, s. 23 n.; tenże, Wstęp, w: tenże, Urzędnicy miejscy Krakowa, s. XIV; M. Wyżga, Ceremonie na ratuszu krakowskim w XV-XVIII wieku, „Roczniki Dziejów Społecznych i Gospodarczych", 74, 2014, s. 145 n.
} 
ofiarowany rajcom w jednym z najbardziej podniosłych momentów życia kościelnego i politycznego gminy miejskiej. Z zamiarem ofiarowania kodeksu w konkretnym terminie może wiązać się również fakt, że księga nie została ukończona ${ }^{30}$. Nie przepisano do niej wszystkich statutów cechowych - na 25 miniatur obrazujących działalność korporacji tylko do 12 dopisano teksty statutów, a także nie dokończono indeksu dokumentów na końcu kopiariusza ani miniatury z herbem miasta Krakowa, umieszczonej we wstępnej części kodeksu, pomiędzy listem dedykacyjnym Behema i kopią przywileju lokacyjnego. Miniator nie zdążył wypełnić kolorem całości postaci św. Wacława i św. Stanisława ani tarczy herbowej nad środkową wieżą muru miejskiego.

Wysoka ranga kodeksu Baltazara Behema znalazła również odbicie w wyglądzie jego oprawy. Został on oprawiony $\mathrm{w}$ deski obciągnięte bordowym aksamitem i zaopatrzone w srebrne okucia ${ }^{31}$. Czerwony aksamit stosowano w tym czasie do pokrycia kodeksów o charakterze luksusowym, przede wszystkim ksiąg liturgicznych. Wygląd ich opraw nawiązywał do symboliki rezurekcyjnej, współgrając z innymi elementami wyposażenia kaplic i ołtarzy ${ }^{32}$. W kancelariach dawnych miast czerwoną barwę rezerwowano dla opraw kodeksów o najwyższej randze publicznoprawnej, zwykle zbiorów tekstów prawnych i kopiariuszy przywilejów, które często nazywano „czerwonymi księgami” (Rote Bücher) ${ }^{33}$. Deski opraw najcenniejszych ksiąg miejskich pokrywano jednak przeważnie skórą. W taki sposób oprawiono najstarszy pergaminowy kodeks tekstów prawa miejskiego będący w posiadaniu rady miejskiej Krakowa, wykonany w $1308 \mathrm{r}^{34}$ Zgodnie z najstarszym inwentarzem ksiąg przechowywanych w kancelarii Krakowa z 1632 r., pierwszy znany krakowski kopiariusz, założony ok. 1375 r. i użytkowany do czasu założenia kodeksu Baltazara Behema, oprawiono w zielony aksamit ${ }^{35}$. Bordowa aksamitna oprawa kodeksu Behema musiała więc prezentować się wyjątkowo uroczyście, nawiązując do XVI-wiecznego karmazynowego obicia ścian Izby Pańskiej ${ }^{36}$. Symboliczną rangę kodeksu Behema podnosiła też miniatura ukazująca Ukrzyżowanie, pierwotnie umieszczona we wgłębieniu tylnej deski oprawy ${ }^{37}$. Krucyfiksy i przedstawienia Ukrzyżowania należały w tym okresie do typowego wyposażenia miejskich sal sądowych $^{38}$. Czas i miejsce powstania miniatury są jednak tematem specjalistycznych dyskusji i nie można

30 P. Wiencierz, Kodeks Baltazara Behema, s. 30.

${ }^{31}$ Kodeks zmieniał trzykrotnie oprawę, w 1878, 1966 i 1986 r. Pierwszą wzmiankę o bordowej oprawie przechował inwentarz krakowskich ksiąg kancelaryjnych z 1632 r.: AN, rkps 1469, s. 7: „Donatus w bordowym axamicie”. Późniejsze opisy kodeksu omawia A. Sobańska, Kodeks Baltazara Behema, s. 15 n.

32 J. Tomaszewski, Oprawy haftowane i tekstylne z XVI-XIX wieku w zbiorach polskich, t. 1: Kontekst historyczny, Warszawa 2013, zwł. s. 18-41; tenże, Oprawa książkowa w Polsce 1450-1600. Studium tegumentologiczno-ikonograficzne, Warszawa 2018, s. 177-181.

33 P. Rehme, Über Stadtbücher als Geschichtsquelle, Halle an der Saale 1913, s. 8; Ch. Wanzeck, Zur Etymologie lexikalisierter Farbwortverbindungen. Untersuchungen anhand der Farben Rot, Gelb, Grün und Blau, Amsterdam-New York 2003, s. 57 n.; M.F. Kluge, Die Macht des Gedächtnisses. Entstehung und Wandel kommunaler Schriftkultur im Mittelalterlichen Augsburg, Leiden 2014, s. 181 n.; zob. też Protokolarz albo „Czerwona księga” Mysłowic, wyd. A. Kowalska, A. Piwowarczyk, red. A. Barciak, Mysłowice 2002.

${ }^{34}$ Katalog lacińskich rękopisów, s. 158; U.-D. Oppitz, Deutsche Rechtsbücher des Mittelalters, t. 2, Köln-Wien 1990, nr 844. W czerwoną safianową skórę oprawiono również ostatni wielki staropolski kopiariusz przywilejów miasta Krakowa, spisany pod koniec XVII w. przez rajcę Zygmunta Jana Zaleskiego; J. Bieniarzówna, Mieszczaństwo krakowskie XVII w. Z badań nad struktura społeczna miasta, Kraków 1969, s. 93 n.; taż, Zygmunt Jan Zaleski (1656-1706) i jego dzieło, „Rocznik Krakowski”, 62, 1996, s. 17-29. Warto zwrócić uwagę, że w deski pokryte czerwoną skórą oprawiono m.in. także najstarszy kopiariusz Wrocławia z początku XIV w., XIV-wieczny wrocławski kodeks prawa ławniczego oraz poznańską księgę prawa magdeburskiego i miśnieńskiego z przełomu XIV i XV w.; B. Turoń, Najstarszy kopiarz miasta Wrocławia, Sobótka, 15, 1960, nr 2, s. 185; U.-D. Oppitz, Deutsche Rechtsbücher, nr 254; W. Maisel, Wstęp, w: Poznańska księga prawa magdeburskiego i miśnieńskiego, wyd. W. Maisel, Wrocław 1964, s. XIV.

${ }_{35}$ AN, rkps 1469, s. 16; por. S. Estreicher, w: Najstarszy zbiór przywilejów i wilkierzy miasta Krakowa, wyd. S. Estreicher, Kraków 1936, s. IV.

36 J. Muczkowski, Dawny krakowski ratusz, „Rocznik Krakowski”, 8, 1906, s. 26; M. Wyżga, Ceremonie na ratuszu krakowskim, s. 145.

37 W 1878 r. deski oprawy zamieniono kolejnością, a w 1966 r. miniaturę odklejono od deski i wklejono do kodeksu (jako k. 206a) bezpośrednio przed karty z rotami przysiąg miejskich; A. Sobańska, Kodeks Baltazara Behema, s. 16.

38 W. Maisel, Archeologia prawna Polski, Warszawa-Poznań 1982, s. 74 n., 167 n.; B. Wyrozumska, Kancelaria miasta Krakowa $w$ średniowieczu, Kraków 1995, s. 44; P. Wiencierz, Iuramentum na inaugurację władzy, s. 348 n.; zob. też 


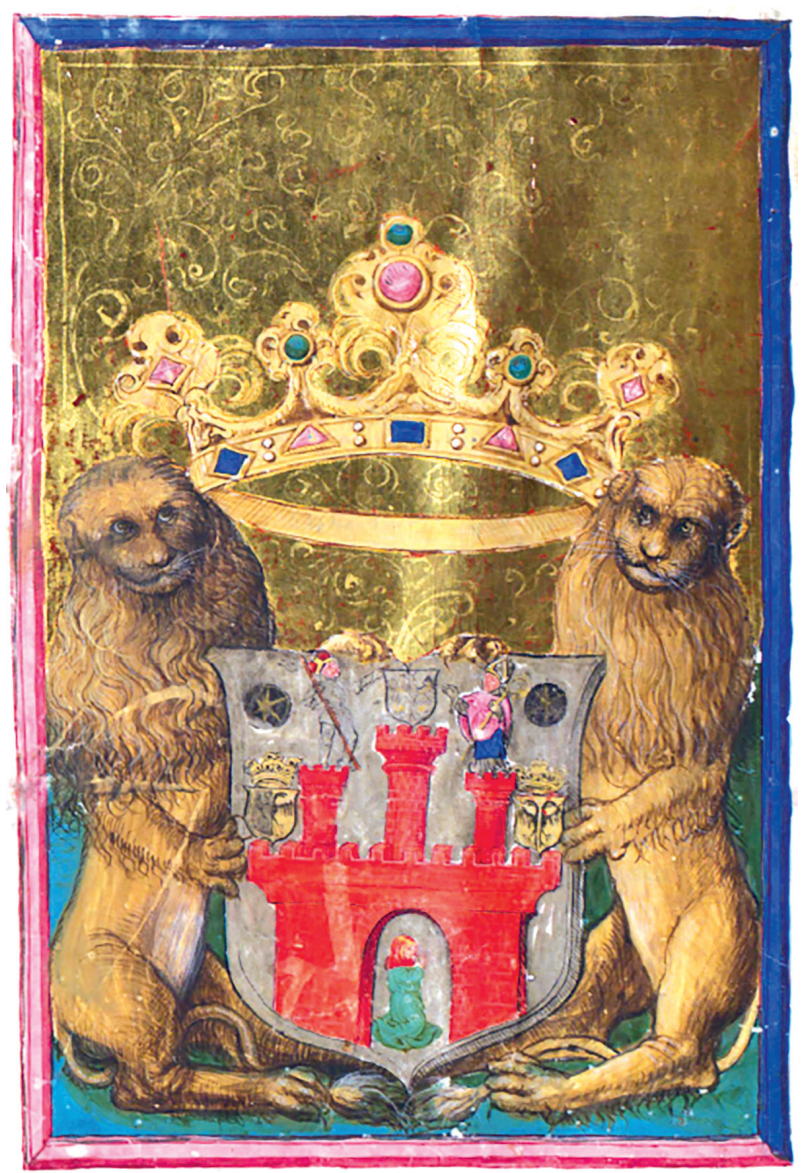

Il. 1. Miniatura herbowa w kodeksie Baltazara Behema; BJ, rkps 16, k. 4v

wykluczyć, że wykonano ją poza warsztatem kodeksu Behema, nawet po ofiarowaniu księgi rajcom ${ }^{39}$. Wyrazem szacunku, jakim otaczano kodeks Behema, był również zwyczaj nazywania go „Donatem”, nawiązujący do klasycznego podręcznika gramatyki Eliusza Donata ${ }^{40}$. W podobny sposób określano najcenniejsze kodeksy w kancelariach wielu innych średniowiecznych i nowożytnych miast ${ }^{41}$.

Jak powszechnie wiadomo, na oprawę ikonograficzną kodeksu Baltazara Behema składa się również miniatura z herbem miasta Krakowa na początku księgi oraz 25 miniatur, które towarzyszą statutom cechowym i obrazują codzienną działalność korporacji składających się na krakowską communitas. Tworzą one obrazowy, satyryczny moralitet, potępiający przywary i wysławiający cnoty krakowskiego mieszczaństwa ${ }^{42}$. Wyrażają także ideę, zgodnie z którą rada miejska była protektorem praw stanowiących o pomyślności całej wspólnoty. Fundamentalne znaczenie dla interpretacji treści symbolicznych utrwalonych $\mathrm{w}$ dekoracji miniatorskiej kopiariusza ma jednak analiza miniatury $\mathrm{z}$ herbem miejskim. $\mathrm{W}$ różowo-niebieskiej ramce na złotym floryzowanym tle widnieje tarcza herbowa o srebrnym polu, trzymana przez dwa złote lwy i zwieńczona koroną otwartą. Interpretacji przedstawienia heraldycznego

B. Wyrozumska, Obyczaj średniowiecznej sali sądowej, „Zeszyty Naukowe Uniwersytetu Jagiellońskiego”, 663, Prace Historyczne, nr 74, 1985, s. 89-95.

39 S. Sawicka, Nieznany krakowski rękopis, s. 74-76; Z. Ameisenowa, Rękopisy i pierwodruki, s. 162 n.; taż, Kodeks Baltazara Behema, s. 33 n.; B. Miodońska, Kodeks Baltazara Behema, s. 371; Z. Rozanow, Sekrety miniatur, s. 45-49.

40 Zwrócił na to uwagę, bez podania źródła informacji, F. Piekosiński, w: KDm.K, t. 1, s. XIII. Kodeks Behema określano „Donatem” m.in. w spisie dochodów miasta Krakowa z 1542 r. (AN, rkps 1567; edycja w: KDm.K, t. 4, s. 723-767) oraz w inwentarzu ksiąg kancelaryjnych z 1632 r. (AN, rkps 1469, s. 7; por. P. Wiencierz, Kodeks Baltazara Behema, s. 17).

${ }^{41}$ R. Schmidt-Wiegand, Rechtsbücher in städtischem Besitz, s. 155.

${ }^{42}$ Z. Rozanow, Mieszczańskie uniwersum, s. 205-215. 


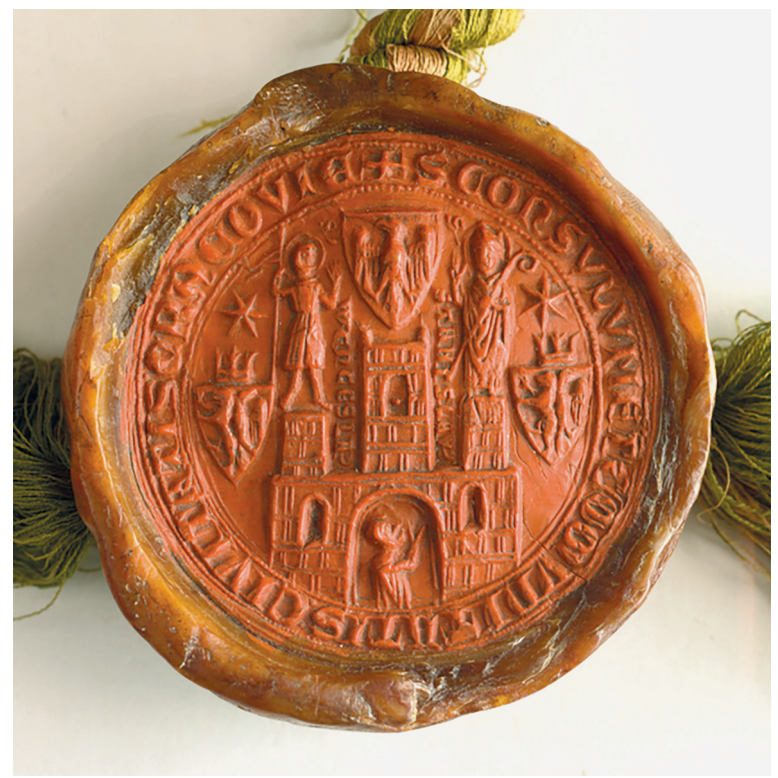

Il. 2. Pieczęć wielka miasta Krakowa przy dokumencie z 27 II 1425; AGAD, dok. perg. nr 5024

na tarczy dokonał Zenon Piech ${ }^{43}$. Badacz słusznie zauważył, że herb w kodeksie nie jest tożsamy z rzeczywistym herbem miasta Krakowa, który do końca XVI w. ukazywał fragment czerwonego muru miejskiego o trzech basztach i otwartej bramie w srebrnym polu. Godło na tarczy herbowej w kodeksie Baltazara Behema nawiązuje natomiast bezpośrednio do przedstawienia w polu wielkiej pieczęci miasta Krakowa, powstałej jeszcze w drugiej połowie XIII w. i poddanej modyfikacjom na początku XIV w. Na pieczęci przedstawiono fragment muru miejskiego z trzema basztami i otwartą bramą, w której klęczy lub stoi zakapturzony orant, zwracając się w geście modlitewnym do św. Stanisława, ustawionego na lewej heraldycznie baszcie. Na prawej baszcie stoi św. Wacław. Nad środkową wieżą unosi się tarcza z nieukoronowanym orłem, prawdopodobnie herbem Bolesława Wstydliwego. Po bokach muru znajdują się dwie tarcze z herbem Leszka Czarnego, połuorłem-połulwem, nakryte koronami. Po lewej i prawej stronie u góry pola pieczęci widnieją dwie sześcioramienne gwiazdy. Jedyna poważna różnica w treści przedstawień w kodeksie i na pieczęci polega na tym, że w kodeksie lewy (heraldycznie) połuorzeł-połulew został zastąpiony dwugłowym czarnym orłem.

Według Z. Piecha twórca miniatury w kodeksie Baltazara Behema nie namalował na początku kopiariusza prawdziwego herbu miejskiego ze względów estetycznych i ideowych: „Chodziło zapewne o to, że we wspaniałym, bogato ilustrowanym zbiorze przywilejów miejskich i statutów cechowych skromny i stereotypowy herb miasta byłby dysonansem". Badacz uważa, że dawne przedstawienie napieczętne mogło „rekompensować”, i to „nawet z naddatkiem”, słabe strony oficjalnego herbu miejskiego. Dalej jednak stwierdził, że miniaturzysta nie rozumiał treści kopiowanego wyobrażenia, skoro na jednej z tarcz na miniaturze namalował omyłkowo dwugłowego orła. Z. Piech podkreślił również, że herb Krakowa na początku kodeksu Baltazara Behema był niezgodny ze sztuką heraldyczną, na jednej tarczy herbowej przedstawiono bowiem trzy kolejne tarcze. Tą drogą doszedł on do konkluzji, że twórca miniatury herbowej w kodeksie „nie zastanawiał się nad tym, co on przedstawia, lecz bezmyślnie skopiował wyobrażenie z najstarszej pieczęci miejskiej" ${ }^{44}$. Wniosek taki wydaje się już na pierwszy rzut oka sprzeczny z przywołanym wcześniej poglądem Z. Piecha, jakoby miniaturzysta podjął w pełni świadomą decyzję o modyfikacji herbu miejskiego w celu podniesienia jego walorów estetycznych i ideowych.

${ }^{43}$ Z. Piech, Skład wzią się i co oznacza Orzech w herbie Krakowa?, w: Venerabiles, nobiles et honesti. Studia z dziejów społeczeństwa Polski średniowiecznej, red. A. Radzimiński, A. Supruniuk, J. Wroniszewski, Toruń 1997, s. 375 n.; por. M. Friedberg, Herb miasta Krakowa, „Rocznik Krakowski”, 28, 1937, s. 109 n.

44 Z. Piech, Skąd wziąt się, s. 377. 
Przedstawiona interpretacja herbu miasta Krakowa w kodeksie Baltazara Behema wydaje się całkowicie chybiona. Należy przede wszystkim zwrócić uwagę, że kompozycja heraldyczna złożona z tarczy trzymanej przez lwy i zwieńczonej koroną nie została wymyślona od podstaw przez miniaturzystę. Zaczerpnięto ją mianowicie z pieczęci większej koronnej Jana Olbrachta ${ }^{45}$. Jedyna różnica między kompozycją heraldyczną w kodeksie Baltazara Behema i na pieczęci Jana Olbrachta polega na tym, że na królewskim sigillum ukazano koronę zamkniętą, wprowadzoną do heraldyki jagiellońskiej za panowania tego władcy i symbolizującą niezależność Polski od Cesarstwa Rzymskiego ${ }^{46}$. Jan Olbracht był natomiast jedynym przedstawicielem dynastii jagiellońskiej, na którego pieczęci przedstawiono lwie trzymacze, będące szczególnie wymownym symbolem monarszej godności ${ }^{47}$. Malarskie przedstawienie tarczy z herbem królewskim trzymanej przez lwy i zwieńczonej koroną zamkniętą znajduje się na odwrociu drugiej karty Mszału jasnogórskiego, fundacji pobożnej Olbrachta, zrealizowanej już po śmierci władcy, ok. 1506-1507 r. ${ }^{48}$ Pod względem kompozycyjnym i kolorystycznym przedstawienie w mszale jest niemal bliźniacze względem miniatury herbowej w kodeksie Behema. Miniator odpowiedzialny za namalowanie herbu w mszale nie był z pewnością tożsamy $\mathrm{z}$ twórcą miniatury ukazującej herb miasta Krakowa, miał jednak niewątpliwie kontakt z warsztatem kodeksu Behema ${ }^{49}$.

Herb miasta Krakowa w kodeksie Baltazara Behema okazuje się kunsztowną kompozycją heraldyczno-sfragistyczną, powstałą z połączenia przedstawienia ukazanego na głównej pieczęci miasta Krakowa z elementami heraldycznymi z głównej pieczęci Jana Olbrachta. Sądzę, że miniatura herbowa na początku kodeksu Behema wyrażała ideę monarszej opieki nad komunalną autonomią i mocą publicznoprawną miejskich przywilejów. Z proponowanej perspektywy można interpretować również obecność czarnego dwugłowego orła w herbie Krakowa. Był to powszechnie rozpoznawany herb Rzeszy Niemieckiej ${ }^{50}$, trudno więc zgodzić się z Z. Piechem, że wprowadzenie takiego symbolu do herbu miejskiego wynikało z nieuwagi miniaturzysty ${ }^{51}$. Decyzja o wyeksponowaniu go na początku uroczystego zbioru miejskich przywilejów musiała zostać gruntownie przemyślana. Możliwe, że twórcy koncepcji kodeksu Behema odwołali się do szeroko rozpropagowanej tradycji, wedle której saskie prawo ziemskie oraz spokrewnione z nim prawo magdeburskie miały status prawa cesarskiego, wywodząc się jeszcze z przywilejów ogłoszonych przez Konstantyna Wielkiego, Karola Wielkiego, Ottona I i Ottona II ${ }^{52}$.

Osobnego namysłu wymagają powody, dla których twórca miniatury herbowej umieszczonej na początku kodeksu Baltazara Behema sięgnął po pieczęć Jana Olbrachta, a nie aktualnie panującego Aleksandra Jagiellończyka. O zamiarze uhonorowania pamięci zmarłego króla w kodeksie Behema świadczy również obszerny nekrolog ku czci Jana Olbrachta, wpisany czerwonym atramentem na karty poprzedzające odpisy przywilejów wystawionych przez tego władcę ${ }^{53}$. Pamięć o Olbrachcie przywołano zapewne także na jednej z miniatur kodeksu, ukazującej malarza, który dekoruje fryz przestronnej

${ }^{45}$ M. Gumowski, Pieczęcie królów polskich, Kraków 1910, s. 21, tab. XII, nr 34; Z. Piech, Monety, pieczęcie i herby w systemie symboli władzy Jagiellonów, Warszawa 2003, s. 67 n.

46 A. Gieysztor, „Non habemus caesarem nisi regem”. Korona zamknięta królów polskich w końcu XV wieku i w wieku XVI, w: Muzeum i twórca. Studia z historii sztuki i kultury ku czci prof. dr. Stanistawa Lorentza, red. K. Michałowski, Warszawa 1969 , s. 283 n

${ }^{47}$ M. Wilska, Królewskie lwy, w: Heraldyka i okolice, red. A. Rachuba, S. Górzyński, H. Manikowska, Warszawa 2002, s. 339-352.

${ }^{48}$ Mszat Jagiellonów z Jasnej Góry, red. R. Pośpiech, Opole 2013. Stan badań nad mszałem podsumowała B. Miodońska, Missale ordinis sancti Pauli eremitae zwane Mszatem jasnogórskim lub Jagiellonów, w: Malarstwo gotyckie w Polsce, s. 315 n.

49 Podobieństwa i różnice między miniaturami omówiła S. Sawicka, Nieznany krakowski rękopis, s. 64 n.; zob. też Z. Rozanow, Sekrety miniatur, s. 42; por. B. Miodońska, Iluminator Mszatu jasnogórskiego i Pontyfikatu Erazma Ciotka, „Rozprawy i Sprawozdania Muzeum Narodowego w Krakowie", 9, 1967, s. 51-77.

${ }^{50} \mathrm{~W}$ badaniach nad kodeksem Baltazara Behema zwróciła na to uwagę dopiero Z. Rozanow, Sekrety miniatur, s. 44.

${ }^{51}$ Z. Piech, Skad wziat sie, s. 377.

${ }^{52}$ H. Lück, Der Sachsenspiegel als Kaiserrecht. Vom universalen Geltungsanspruch eines partikularen Rechtsbuches, w: Heiliges Römisches Reich Deutscher Nation 962 bis 1806. Altes Reich und neue Staaten 1495 bis 1806, t. 1, red. H. Ottomeyer, J. Götzmann, Dresden 2006, s. 263-273.

${ }^{53}$ BJ, rkps 16, k. 159r-160r. Nadmieńmy, że niedługo po pogrzebie króla krótszy nekrolog wpisano na pierwszą kartę księgi radzieckiej założonej w 1500 r.; M. Starzyński, Dwa nekrologi, s. 127-136. 
izby, być może Izby Pańskiej na ratuszu krakowskim, w obecności pięciu mężczyzn, prawdopodobnie rajców ${ }^{54}$. Na ścianie na wprost widnieją m.in. purpurowe tarcze z Orłem i Pogonią trzymane przez dwóch heroldów, a ponad tarczami przedstawiono szarfę z inskrypcją ${ }^{55}$. Napis na szarfie jest praktycznie nieczytelny, zdaje się jednak nie ulegać wątpliwości, że w drugim wierszu inskrypcji widnieje wyraz „Alberti” - być może drugie imię Jana Olbrachta w formie dopełniaczowej ${ }^{56}$. Słabiej czytelna cyfra rzymska XXVII w pierwszym wierszu inskrypcji może natomiast odnosić się do dnia elekcji królewskiej Olbrachta, 27 VIII 1492, przywołanej także na początku wspomnianego nekrologu ${ }^{57}$. Powodów wyróżnienia Jana Olbrachta w kodeksie Baltazara Behema należy doszukiwać się w wielkim przywileju dla Krakowa, wystawionym przez niego w 1493 r. w Piotrkowie ${ }^{58}$. Król potwierdził wszystkie dotychczasowe wolności miasta, podkreślając, że wydany przez niego przywilej jest równy konfirmacjom ziemskim, a więc przywilejom szlacheckim. Przywilej z 1493 r. traktowano jako akt inkorporacji Krakowa do stanu szlacheckiego i wykorzystywano jako argument w zabiegach o zrównanie mieszczan krakowskich w prawach politycznych ze szlachtą ${ }^{59}$. Nieprzypadkowo wątek rywalizacji o wpływy polityczne między obywatelami Krakowa i szlachtą wybrzmiał właśnie w nekrologu Jana Olbrachta zamieszczonym w kodeksie Behema. Przypomniano w nim, że król zwykł konsultować istotne decyzje z rajcami i przedniejszymi obywatelami Krakowa, co powodowało zawiść u szlachty: „O regem civibus acceptum, cuius frequens cum consulatu ac ceteris magnificis civibus in arduis negociis consultacio liberalisque ac humana conversacio invidiam apud nobilitatem peperit".

Treści ideowe utrwalone w kodeksie Baltazara Behema stanowiły prawdopodobnie odpowiedź na wydarzenia polityczne, które rozgrywały się w Królestwie Polskim w pierwszych latach XVI w. Prace nad krakowskim kopiariuszem przypadły mianowicie na okres burzliwych reform ustroju państwowego, podejmowanych $\mathrm{w}$ otoczeniu Aleksandra Jagiellończyka ${ }^{60}$. Starania reformatorskie nasiliły się zwłaszcza jesienią 1503 r., kiedy po zakończeniu wojny z Moskwą Aleksander powrócił z Litwy do Polski, a dotychczasowy sekretarz królewski Jan Łaski został mianowany kanclerzem wielkim koronnym $^{61}$. Głównym owocem działalności Łaskiego była całościowa kodyfikacja polskiego prawa ziemskiego, nazywana zwyczajowo Statutem Łaskiego ${ }^{62}$. Zgodnie z przedrukowanym w Statucie królewskim

${ }^{54}$ BJ, rkps 16, k. 273r; Z. Rozanow, Mieszczańskie uniwersum, s. 208; taż, Sekrety miniatur, s. 84-88.

${ }_{55}$ M.A. Janicki, Inskrypcja w przestrzeni publicznej - przykład Krakowa i Małopolski w XIV-XV wieku. Uwagi historyczne i metodologiczne, w: Historia społeczna późnego średniowiecza. Nowe badania, red. S. Gawlas, M.T. Szczepański, Warszawa 2011, s. 270.

${ }^{56}$ Por. dotychczasowe, wielce hipotetyczne propozycje odczytu całości inskrypcji: J. Ptaśnik, Codex picturatus, s. 20; Z. Ameisenowa, Kodeks Baltazara Behema, s. 38; Katalog tacińskich rękopisów, s. 17; B. Miodońska, Kodeks Baltazara Behema, s. 370; Z. Rozanow, Sekrety miniatur, s. 86.

${ }^{57}$ F. Papée, Jan Olbracht, Kraków 2006 (na podst. wyd. z 1949), s. 36 n.

${ }^{58} \mathrm{KDm} . \mathrm{K}$, t. 1, nr 204.

${ }^{59}$ Inkorporację miasta Krakowa do rycerstwa ziemi krakowskiej potwierdził w 1513 r. Zygmunt Stary: Prawa, przywileje i statuta miasta Krakowa (1507-1795), t. 1: 1507-1586, cz. 1, wyd. F. Piekosiński, Kraków 1885, nr 7; zob. L. Rymar, Udział Krakowa w sejmach i sejmikach Rzeczypospolitej, „Rocznik Krakowski”, 7, 1904, s. 199 n.; J. Ptaśnik, Miasta i mieszczaństwo w dawnej Polsce, Kraków 1934, s. 271-274; A. Karpiński, Mieszczanie krakowscy na sejmach Rzeczypospolitej w XVI-XVIII w. Zarys problematyki, w: Spoleczeństwo staropolskie. Seria nowa, t. 1: Spoleczeństwo a polityka, red. I. Dacka-Górzyńska, A. Karpiński, Warszawa 2008, s. 44; zob. też T. Wasilewski, Nobilitacje miast w dawnej Rzeczypospolitej Obojga Narodów, w: Czas, przestrzeń, praca w dawnych miastach. Studia ofiarowane Henrykowi Samsonowiczowi w sześćdziesiąta rocznicę urodzin, red. A. Wyrobisz, M. Tymowski, Warszawa 1991, s. 373-385.

${ }^{60}$ F. Papée, Przywilej mielnicki, w: Księga pamiątkowa ku czci Oswalda Balzera, t. 2, red. W. Abraham, P. Dąbrowski, L. Pieniński, Lwów 1926, s. 173-187; L. Sobolewski, W. Uruszczak, Artykuły mielnickie z roku 1501, Czas. Pr. Hist., 42, 1990, nr 1-2, s. 51-80; J. Bardach, O stawaniu się sejmu polskiego we współczesnej historiografi, w: Parlamentaryzm w Polsce we wspótczesnej historiografii, red. J. Bardach, Warszawa 1995, s. 44 n.; S. Gawlas, Początki polskiego sejmu: problemy i dyskusje, w: Systemy reprezentacji i parlamentaryzm $w$ Europie Środkowej w rozwoju historycznym, red. A. Barciak, Katowice-Zabrze 2016, s. 134 n.

${ }^{61}$ F. Papée, Aleksander Jagiellończyk, Kraków 2006 (na podst. wyd. z 1949), s. 76 n.; P. Tafiłowski, Jan Laski (1456-1531): kanclerz koronny i prymas Polski, Warszawa 2007, s. 34 n.

${ }^{62}$ W. Uruszczak, Commune incliti Poloniae Regni privilegium constitutionum et indultuum. O tytule i mocy prawnej Statutu Łaskiego z 1506 r., w: Prace poświęcone pamięci Adama Uruszczaka, red. J. Halberda, M. Hosowicz, A. Karabowicz, 
przywilejem konfirmacyjnym, z oficjalną prośbą o przygotowanie kodyfikacji praw wystąpili przed władcą m.in. posłowie ziem i miast (,prelati barones terrarumque et civitatum nuntii”) zgromadzeni na sejmie radomskim w 1505 r. ${ }^{63}$ Według legacji Aleksandra na jesienny sejmik w Kole w 1505 r. druk Statutu miał nastąpić przed Bożym Narodzeniem: „Quorum impressio ante Natale finietur”. Przypomnijmy, że w podobnym terminie w kancelarii miasta Krakowa starano się ukończyć kodeks Baltazara Behema. Monarcha ogłosił również, że wybrane egzemplarze Statutu zostaną oprawione, opieczętowane i przekazane do ważniejszych kościołów i siedzib sądów ziemskich, a inne egzemplarze, bez pieczęci, będą wystawione na targi ${ }^{64}$. Decyzja o sporządzeniu kodeksu Baltazara Behema w latach 1503-1505 może świadczyć o dążeniach rajców Krakowa do zabezpieczenia przywilejów miejskich w obliczu przesilenia politycznego w państwie.

Kodeks Baltazara Behema był więc nie tylko kopiariuszem mającym usprawnić działalność kancelarii miejskiej, lecz także politycznym symbolem wyrażającym oficjalną miejską ideologię władzy. Decyzja o ofiarowaniu kodeksu rajcom w okresie bożonarodzeniowym mogła wynikać z zamiaru wykorzystywania go jako insygnium w trakcie styczniowych ceremonii zaprzysiężenia rady miejskiej ${ }^{65}$. Praktyka polegająca na eksponowaniu cennych kodeksów praw i przywilejów podczas uroczystego zaprzysiężenia władz komunalnych znajduje szerokie poświadczenie w wielu miastach średniowiecznej i nowożytnej Europy ${ }^{66}$. Zwyczaj taki ilustruje wyjątkowo sugestywnie jedna z miniatur kodeksu prawa miejskiego Hamburga z 1497 r., na której ukazano uroczyste zgromadzenie rajców zasiadających na ławach wokół stołu nakrytego zieloną wzorzystą tkaniną ${ }^{67}$. Mniej więcej pośrodku przedstawienia jeden $\mathrm{z}$ rajców, prawdopodobnie burmistrz, unosi lewą dłoń w geście przysięgi i składa prawą dłoń na złotym relikwiarzu ustawionym na stole. Podniesiona ręka i relikwiarz wyznaczają oś pionową przedstawienia. Poniżej, również na osi, widnieje księga w czerwonej oprawie, trzymana demonstracyjnie przez dwóch rajców i zapewne tożsama z kodeksem, w którym namalowano omawianą miniaturę. Wykorzystywanie kodeksu Baltazara Behema jako insygnium podczas elekcji rady miejskiej poświadcza dosłownie dopiero zapiska w katalogu rajców krakowskich założonym w $1678 \mathrm{r}$. i prowadzonym na bieżąco do drugiej połowy XVIII w. Opisano w niej przekazanie ,insygniów urzędów" radzie miejskiej wybranej 16 IV 1792 w związku z uchwaleniem Konstytucji 3 maja ${ }^{68}$. Wśród przedmiotów wręczonych rajcom wymieniona została m.in. „księga $\mathrm{w}$ aksamit oprawna $\mathrm{z}$ narożnikami srebrnymi, w której prawa miasta i cechów na pergaminie wpisane", niewątpliwie kodeks Baltazara Behema ${ }^{69}$.

Kraków 2006, s. 115-136; tenże, Statut Jana Łaskiego z 1506 roku. 500 lat tradycji państwa prawa w Polsce, Czas. Pr. Hist., 59, 2007, nr 2, s. 9-19.

${ }_{63}$ VL, t. 1, cz. 1, s. 171 n.; W. Uruszczak, ,,Sejm walny wszystkich państw naszych”. Sejm w Radomiu z 1505 r. i Konstytucja Nihil novi, Czas. Pr. Hist., 57, 2005, nr 1, s. 11-27.

${ }^{64}$ Akta Aleksandra króla polskiego, wielkiego księcia litewskiego i t. d. (1501-1506), wyd. F. Papée, Kraków 1927, nr 303, s. 513 n.; F. Papée, Aleksander Jagiellończyk, s. 104 n.; W. Uruszczak, Commune incliti, s. 116 n. Według explicitu dzieło opuściło drukarnię Jana Hallera dopiero 27 I 1506: Jan Łaski, Commune incliti Poloniae Regni privilegium constitutionum et indultuum, Kraków 1506, k. 68v. Królewski egzemplarz Statutu, wydrukowany na pergaminie i opatrzony pieczęcią większą koronną, przechowywano w skarbcu koronnym w skrzyni z regaliami; M. Myśliński, Klejnoty Rzeczypospolitej. Zawartość Skarbca Koronnego na Wawelu w świetle jego inwentarzy z lat 1475-1792, Warszawa 2007, s. 172, 201; P. Węcowski, Skarbiec pamięci. Archiwum monarsze w Polsce do początków XVI wieku, w: Przeszłość w kulturze średniowiecznej Polski, t. 1, red. J. Banaszkiewicz, A. Dąbrówka, P. Węcowski, Warszawa 2018, s. 393 n.

${ }^{65}$ P. Wiencierz, Iuramentum na inaugurację władzy, s. 349 n.; zob. też M. Duda, S. Jóźwiak, Sposoby składania przysięgi w państwie Zakonu Krzyżackiego w Prusach w późnym średniowieczu-zarys problematyki, Zap. Hist., 79, 2014, nr 1, s. 5-36.

${ }^{66}$ M.F. Kluge, Die Macht des Gedächtnisses, s. 205 n.

${ }^{67}$ B. Binder, Illustriertes Recht. Die Miniaturen des Hamburger Stadtrechts von 1497, Hamburg 1988, s. 5-10; H.S. Hayduk, Rechtsidee und Bild, s. 122 n.

68 J.M. Małecki, Kraków w dobie Oświecenia, w: J. Bieniarzówna, J.M. Małecki, Dzieje Krakowa, t. 2: Kraków w wiekach XVI-XVIII, Kraków 1984, s. 593 n.; Z. Noga, w: Urzędnicy miejscy Krakowa, s. XXVI, s. 175.

${ }^{69}$ AN, rkps 1477, k. 113 (119). Ustęp ten przedrukował A. Grabowski, Dawne zabytki miasta Krakowa, Kraków 1850, s. 8 n. W sprawie XVII-wiecznego katalogu rajców krakowskich zob. Z. Noga, Ratusz - archiwum pamięci, „Roczniki Dziejów Społecznych i Gospodarczych", 74, 2014, s. 177. 
Dokonajmy zestawienia najważniejszych wniosków z przedstawionych rozważań.

1. Kodeks Baltazara Behema tworzono w latach 1503-1505. Treść wstępnej partii kopiariusza przemawia jednoznacznie przeciwko możliwości wcześniejszego datowania rozpoczęcia prac pisarskich, przyjmowanej przez M. Starzyńskiego i P. Wiencierz.

2. Kodeks nie powstał jako indywidualna fundacja Baltazara Behema, jak suponowała niedawno P. Wiencierz, lecz był oficjalną fundacją rady miasta Krakowa. Realizację tego zadania powierzono Behemowi jako przełożonemu krakowskiej kancelarii miejskiej.

3. Kodeks Baltazara Behema wyrażał oficjalny program polityczny władz miasta Krakowa. Uwypuklał on rolę rady miejskiej jako protektora krakowskich praw i przywilejów, a także rolę władzy królewskiej jako najwyższego gwaranta ich mocy publicznoprawnej.

4. Twórcy kodeksu Behema dążyli również do utrwalenia pamięci o Janie Olbrachcie, przedstawiając go jako dobrodzieja i obrońcę krakowskiej wspólnoty komunalnej, odpowiedzialnego za zrównanie mieszczan krakowskich w prawach ze stanem szlacheckim.

5. Program ideowy kodeksu Baltazara Behema powstał jako odpowiedź na wyzwania polityczne, jakim była reforma ustroju państwa za panowania Aleksandra Jagiellończyka.

6. Kodeks Behema wykorzystywano nie tylko jako kopiariusz, lecz traktowano go zapewne również jako insygnium władzy. Od czasu ofiarowania go radzie miejskiej na Boże Narodzenie w 1505 r. mógł on uświetniać styczniowe uroczystości zaprzysiężenia rajców.

\section{Baltazar Behem's Codex as the testimony to the urban ideology of power}

Summary: The article is a contribution to the discussion on political and ideological circumstances of the compilation of the Codex of Baltazar Behem, a richly-illuminated cartulary of the municipal council of the city of Cracow from the early years of the $16^{\text {th }}$ century. The author argues that the Cracow cartulary was being made between 1503 and 1505, and polemicizes with the opinion of some researchers who claim that the codex was compiled as a private foundation of Baltazar Behem, head of the Cracow municipal chancellery in 1500-1508. According to one of the main theses put forward in the article, Behem's Codex was prepared as an official foundation of the Cracow City Council, and Baltazar Behem only supervised its compilation. The book expressed the official political programme of the municipal authorities, casting the City Council in the role of protector of the whole Cracow rights and privileges, and the king in the role of supreme guarantor of their public legal power. The authors of the Codex also sought to commemorate King Jan Olbracht deceased in 1501, presenting him as a great benefactor and defender of Cracow urban community, who made equal the political rights of townspeople and the nobility. The ideological programme of the Codex was a response to political challenges resulting from the reform of state political system under Alexander Jagiellon. The Codex of Behem was used not only as a chancellery tool but also as an insignium of authority and power. From the moment it was given to the City Council at Christmas of 1505 , it could add splendour to January ceremonies of swearing-in of councillors.

Nota o autorze: Piotr Okniński, dr, pracownik Instytutu Historii im. Tadeusza Manteuffla Polskiej Akademii Nauk w Warszawie. Jego zainteresowania badawcze koncentrują się wokół problematyki dziejów miast i mieszczaństwa średniowiecznej i nowożytnej Europy.

Author: Piotr Okniński, PhD, employed at the Tadeusz Manteuffel Institute of History, Polish Academy of Sciences. His research focuses on the issues of medieval and early modern urban history.

Instytut Historii im. Tadeusza Manteuffla

Polska Akademia Nauk

ul. Rynek Starego Miasta 29/31

00-272 Warszawa

e-mail: p.okninski89@gmail.com 


\section{Bibliografia}

\section{Źródła drukowane}

Akta Aleksandra króla polskiego, wielkiego księcia litewskiego i t. d. (1501-1506), wyd. F. Papée, Kraków 1927

Kodeks dyplomatyczny miasta Krakowa, t. 1-4, wyd. F. Piekosiński, Kraków 1879-1882

Das „Leobschützer Rechtsbuch”, oprac. G. Roth, red. W. Irgang, Marburg 2006

Mszat Jagiellonów z Jasnej Góry, red. R. Pośpiech, Opole 2013

Najstarszy zbiór przywilejów i wilkierzy miasta Krakowa, wyd. S. Estreicher, Kraków 1936

Poznańska księga prawa magdeburskiego i miśnieńskiego, wyd. W. Maisel, Wrocław 1964

Prawa, przywileje i statuta miasta Krakowa (1507-1795), t. 1: 1507-1586, cz. 1, wyd. F. Piekosiński, Kraków 1885

Protokolarz albo „Czerwona księga” Mysłowic, wyd. A. Kowalska, A. Piwowarczyk, red. A. Barciak, Mysłowice 2002

Volumina legum, t. 1, Petersburg 1859

\section{Opracowania}

Ameisenowa Z., Kodeks Baltazara Behema, Warszawa 1961

Binder B., Illustriertes Recht. Die Miniaturen des Hamburger Stadtrechts von 1497, Hamburg 1988

Estreicher K., Miniatury Kodeksu Bema oraz ich treść obyczajowa, „Rocznik Krakowski”, 24, 1933, s. 199-244

Hayduk H.S., Rechtsidee und Bild. Zur Funktion und Ikonografie der Bilder in Rechtsbücher vom 9. bis zum 16. Jahrhundert, Wiesbaden 2011

Heyzmann U., Balthazaris Behem Codex Picturatus anno 1505, continens privilegia et plebiscita urbis Cracoviae, „Archiv für Kunde österreichischer Geschichts-Quellen”, 33, 1865, s. 163-231

Karpiński A., Mieszczanie krakowscy na sejmach Rzeczypospolitej w XVI-XVIII w. Zarys problematyki, w: Spoteczeństwo staropolskie. Seria nowa, t. 1: Społeczeństwo a polityka, red. I. Dacka-Górzyńska, A. Karpiński, Warszawa 2008, s. 39-63

Kluge M.F., Die Macht des Gedächtnisses. Entstehung und Wandel kommunaler Schriftkultur im Mittelalterlichen Augsburg, Leiden 2014

Lück H., Der Sachsenspiegel als Kaiserrecht. Vom universalen Geltungsanspruch eines partikularen Rechtsbuches, w: Heiliges Römisches Reich Deutscher Nation 962 bis 1806. Altes Reich und neue Staaten 1495 bis 1806, t. 1, red. H. Ottomeyer, J. Götzmann, Dresden 2006, s. 263-273

Miodońska B., Kodeks Baltazara Behema, w: Malarstwo gotyckie w Polsce. Katalog zabytków, red. A.S. Labuda, K. Secomska, Warszawa 2004, s. 370-372

Noga Z., Krakowska rada miejska w XVI wieku. Studium o elicie władzy, Kraków 2003

Okniński P., Oficjalna przeszłość miasta, w: Przeszłość w kulturze średniowiecznej Polski, t. 2, red. H. Manikowska, Warszawa 2018, s. 177-201

Oppitz U.-D., Deutsche Rechtsbücher des Mittelalters, t. 1-3, Köln-Wien 1990

Piech Z., Skład wzią się i co oznacza Orzech w herbie Krakowa?, w: Venerabiles, nobiles et honesti. Studia $z$ dziejów społeczeństwa Polski średniowiecznej, red. A. Radzimiński, A. Supruniuk, J. Wroniszewski, Toruń 1997, s. 369-388

Ptaśnik J., Codex picturatus Baltazara Behema. Problem autorstwa, Kwart. Hist., 44, 1930, nr 1, s. 1-25

Rozanow Z., Mieszczańskie uniwersum Kodeksu Baltazara Behema, w: Sztuka miast i mieszczaństwa XV-XVIII wieku w Europie Środkowowschodniej, red. J. Harasimowicz, Warszawa 1990, s. 205-216

Rozanow Z., Sekrety miniatur Kodeksu Baltazara Behema, Katowice 2017

Sawicka S., Nieznany krakowski rękopis iluminowany z początku XVI wieku, „Studia Renesansowe”, 2, 1957, s. $5-90$

Schmidt-Wiegand R., Text und Bild in den Codices picturati des „Sachsenspiegels”. Überlegungen zur Funktion der Illustration, w: Text-Bild Interpretation. Untersuchungen zu den Bilderhandschriften des Sachsenspiegels, red. D. Hüpper, München 1986, s. 11-31

Sobańska A., Kodeks Baltazara Behema. Komentarz kodykologiczny, Kraków 2007

Starzyński M., Kto byt pisarzem „Kodeksu Behema”?, „Rocznik Krakowski”, 73, 2007, s. 61-71

Tomaszewski J., Oprawa ksiązkowa w Polsce 1450-1600. Studium tegumentologiczno-ikonograficzne, Warszawa 2018 
Uruszczak W., Commune incliti Poloniae Regni privilegium constitutionum et indultuum. O tytule $i$ mocy prawnej Statutu Łaskiego z 1506 r., w: Prace poświęcone pamięci Adama Uruszczaka, red. J. Halberda, M. Hosowicz, A. Karabowicz, Kraków 2006, s. 115-136

Wiencierz P., Iuramentum na inaugurację władzy w mieście średniowiecznym. Przykład Krakowa, „Czas. Pr. Hist.”, 69, 2017, nr 2, s. 331-352

Wiencierz P., Kodeks Baltazara Behema jako kopiariusz. Nowe dyskusje i nowe ustalenia, „Rocznik Krakowski”, 84, 2018, s. 7-32

Wyżga M., Ceremonie na ratuszu krakowskim w XV-XVIII wieku, „Roczniki Dziejów Społecznych i Gospodarczych", 74, 2014, s. 139-159 